\title{
Spatial heterogeneity and seasonal succession of phytoplankton functional groups along the vertical gradient in a mesotrophic reservoir
}

\author{
Tuğba Ongun Sevindik ${ }^{1 *}$, Kemal Çelik $^{2}$ and Luigi Naselli-Flores ${ }^{3}$ \\ 1 Department of Biology, Faculty of Arts and Science, Sakarya University, 54187, Sakarya, Turkey \\ 2 Department of Biology, Faculty of Arts and Science, Balıkesir University, 10145, Balıkesir, Turkey \\ 3 Department of Biological, Chemical and Pharmaceutical Sciences and Technologies (STEBICEF), Section of Botany and \\ Plant Ecology, University of Palermo, Via Archirafi 38, I-90123 Palermo, Italy
}

Received 26 September 2016; Accepted 15 December 2016

\begin{abstract}
Tracking morphological variability of phytoplankton is a useful tool to better understand environmental changes. Highly dynamic systems such as reservoirs are convenient environments to investigate the effects of environmental variables on phytoplankton morphology. However, to fully understand the effects of mixing and trophic state on phytoplankton functional group (FG) distribution, the entire water column must be considered since integrated or sub-superficially collected samples, may not adequately represent phytoplankton structure. This idea was tested by analyzing vertical profiles of phytoplankton FGs, their relative biomass, physical and chemical parameters, through monthly samplings over a 2 years period, at three stations located along the longitudinal axis in the monomictic, mesotrophic İkizcetepeler reservoir, northwestern part of Turkey. Thermal stratification occurred in the reservoir from April to September, and $z_{\text {mix }} / z_{\text {eu }}$ values increased after the breaking down of the thermocline. Nine FGs characterized the seasonal cycle and C-strategist organisms were typical representatives of the assemblages. Nutrient availability and temperature were found to influence phytoplankton dynamics, whereas water withdrawal played a secondary role. Groups Y, P, B, J, F, Lo and Tc showed heterogeneous distribution along the water column and, temperature heterogeneity, high DIN values in surface waters, $z_{\text {mix }} / z_{\text {eu }}$ values and sedimentation loss were the most important factors regulating their distribution. The results show that phytoplankton morphological spectrum throughout the entire water column, contributes useful information to assess the influence of mixing and trophic state on phytoplankton dynamics in mesotrophic reservoirs.
\end{abstract}

\section{Introduction}

Key words: C-S-R strategies / freshwater phytoplankton / functional groups / mesotrophic reservoir

In the last few years, a large number of reservoirs have been created all over the world to store water for domestic water supply, irrigation, navigation, recreation, sedimentation control, flood control and to hydropower (ICOLD, 2007; Zarfl et al., 2015). These ecosystems therefore represent important elements of Earth's freshwater network although they often lie in the upper part of the trophic spectrum and their water exploitation can be seriously compromised by the occurrence of toxic cyanobacteria blooms (Naselli-Flores et al., 2007). Conversely to natural lakes, reservoirs are actually subjected to operational procedure, which may interfere with their physical, chemical and biological characteristics (Naselli-Flores, 2000; Rangel et al., 2012). In particular,

\footnotetext{
*Corresponding author: tsevindik@sakarya.edu.tr
}

Mediterranean reservoirs show wide water-level fluctuations, which may influence the ratio between mixing depth and euphotic depth and ultimately influence phytoplankton structure (Naselli-Flores, 2014).

Spatial heterogeneity of phytoplankton in reservoirs has been largely investigated both vertically and horizontally (e.g., Albay and Akçaalan, 2003; Borges et al., 2008; Rychtecký and Znachor, 2011). Morpho-functional (e.g., shape, size, presence of flagella, presence of mucilage, coloniality) and physiological (photosynthetic efficiency, nutrient uptake and mixotrophic ability, buoyancy regulation, etc.) traits of phytoplankton play an important role in their heterogeneous vertical distribution (Lindholm, 1992; Tremblay et al., 1997; Serra et al., 2003) and represent adaptive strategies to allow phytoplankton assemblages to compel with changes in environmental conditions. Reynolds (2006) showed that phytoplankton growth strategies in a lake at a given time could be 


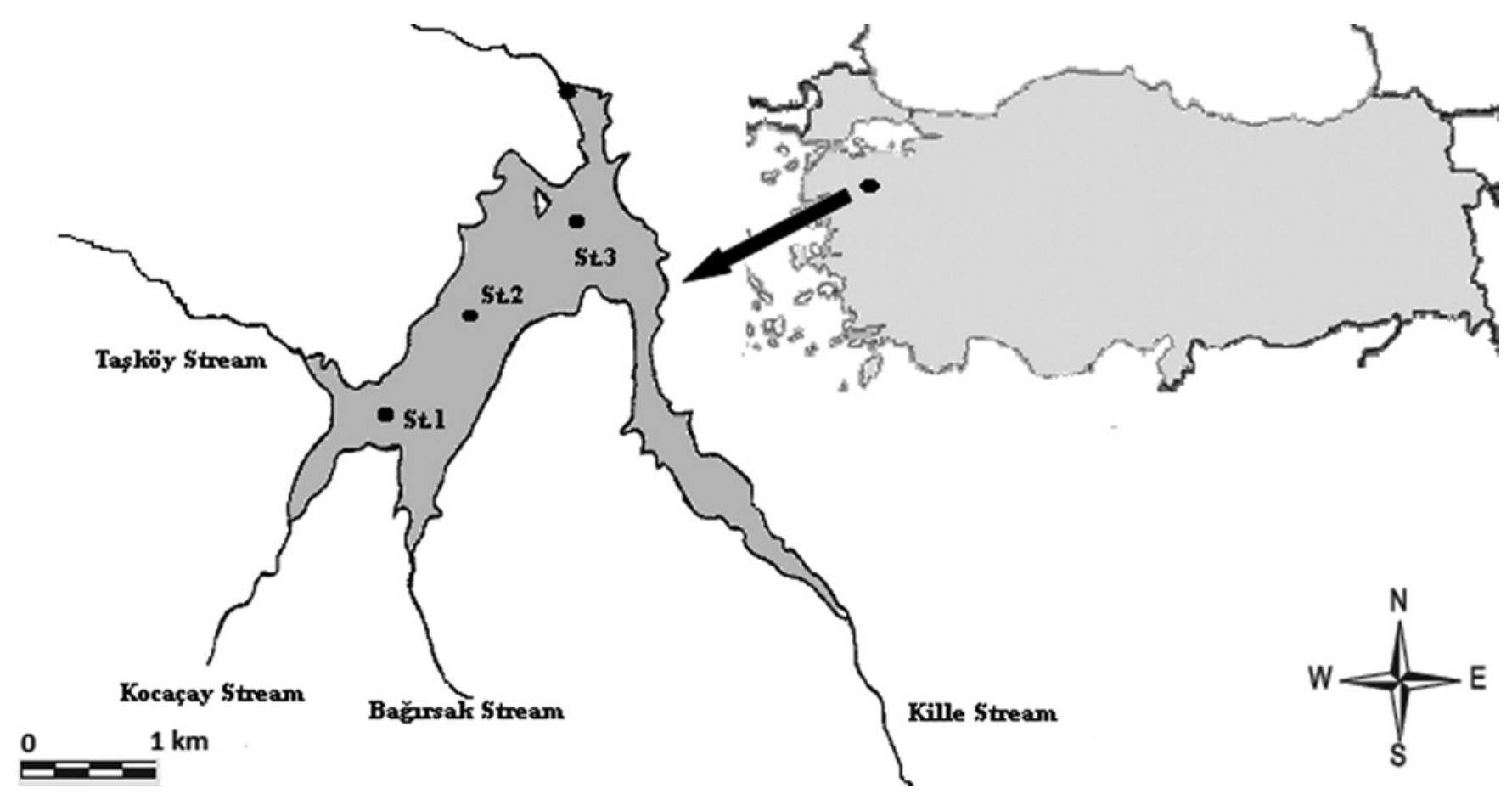

Fig. 1. The map of the İkizcetepeler reservoir and the location of sampling stations.

predicted from the environmental conditions prevailing in the water column. These conditions are largely determined by two key variables: the ratio between the depth of the mixing zone and the euphotic depth $\left(z_{\text {mix }} / z_{\text {eu }}\right)$, which represents a proxy of underwater light climate, and nutrient availability (Naselli-Flores and Barone, 2011). In Sicilian reservoirs, Naselli-Flores (2000) observed that in the higher part of the trophic spectrum, where nutrients are seldom (if ever) limiting phytoplankton growth, the $z_{\text {mix }} / z_{\text {eu }}$ ratio is the main constraint for phytoplankton functional composition, strongly controlling the phytoplankton morphological characteristics and the seasonal succession of functional groups (FGs). In contrast, the influence of nutrients on the phytoplankton morphologies appeared to be higher in the lower part of the trophic spectrum. Phytoplankton morphological variability can thus supply important information on the ecological conditions (nutrient and light availability) of a given water body (Naselli-Flores, 2014). Moreover, the FGs approach (Reynolds et al., 2002; Padisák et al., 2009), based on the physiological, morphological and ecological attributes of the species, has been proved to be an efficient way to analyze seasonal changes in phytoplankton dynamics (Salmaso et al., 2015). The functional classification approach has been successfully applied in reservoirs (e.g., Crossetti and Bicudo, 2008; Becker et al., 2010; Rychtecký and Znachor, 2011) and can reveal the ecological status of aquatic ecosystems independently from their geographic location (Padisák et al., 2006). However, previous studies mainly focused on the temporal distributions of FGs without investigating their vertical variability (Fonseca and Bicudo, 2008; Becker et al., 2009a; Xiao et al., 2011). On the other hand, to our knowledge, vertical distribution of FGs was not investigated in Mediterranean reservoirs and only a short-term study (Becker et al., 2009b) and a long-term one (Crossetti and Bicudo, 2008) were performed in tropical Brazilian reservoirs.

The aim of this study is to test the hypothesis that the interplay of mixing regime and trophic state influences phytoplankton FG distribution throughout the entire water column. Therefore surface sampling, especially during stratification periods, only gives just a partial result of the phytoplankton structure and dynamics in reservoirs, especially in those at the lower side of the trophic spectrum. To support this idea, we studied the phytoplankton dynamics both on a morphology-based approach and according to the FGs classification following Reynolds et al. (2002) and Padisák et al. (2009) along the vertical gradient in monomictic and mesotrophic Mediterranean reservoir during a 2 years study.

\section{Materials and methods}

\section{Study area}

Ikizcetepeler reservoir is a mesotrophic (Carlson, 1977; OECD, 1982; Karadžić et al., 2010) man-made lake with an annual mean chlorophyll $a$ concentration of $4.8 \mu \mathrm{g} . \mathrm{L}^{-1}$ and an average Secchi disc depth of $1.64 \mathrm{~m}$. The reservoir, located at $39^{\circ} 29^{\prime} \mathrm{N}, 27^{\circ} 56^{\prime} \mathrm{E}$ in the Mediterranean part of Turkey (Fig. 1), is a slightly dendritic, warm monomictic water body. It lies at $175 \mathrm{~m}$ above the sea level and has a maximum depth of $25 \mathrm{~m}$, a length of $6.34 \mathrm{~km}$, and a surface area of $10 \mathrm{~km}^{2}$. The reservoir was built in 1992 and it is used for irrigation and to provide drinking 
water (State Water Works, 2005). Its catchment area has been subjected to agricultural, urban and industrial development, which resulted in the deterioration of the water quality (Turkish Ministry of Environment and Forestry, 2007). Data on its phytoplankton taxonomic composition and vertical and seasonal distribution of chlorophyll $a$ are available in Sevindik et al. (2011), Çelik and Sevindik (2011) and Sevindik and Çelik (2012).

Three sampling stations were selected along the main axis of the reservoir to investigate the differences occurring in the riverine, transition and lacustrine zones. During the studied period, water depth ranged between 5 and $10 \mathrm{~m}$ at the riverine station, between 8 and $14 \mathrm{~m}$ at the transition station, while it was between 10 and $20 \mathrm{~m}$ at the lacustrine station.

\section{Phytoplankton analysis}

Sampling was carried out monthly at the three stations between February 2007 and January 2009. Samples were collected at $1 \mathrm{~m}$ intervals using a $1 \mathrm{~L}$ Hydrobios water sampler, between 9:00 and 11:30 a.m., placed in $250 \mathrm{~mL}$ glass bottles, and fixed with Lugol's solution. In the laboratory, the samples were shaken and poured into $50 \mathrm{~mL}$ graduated cylinders. At the end of a $24 \mathrm{~h}$ settling period, $45 \mathrm{~mL}$ of water was siphoned off and the remaining $5 \mathrm{~mL}$ of water was poured into a small glass vial for microscopic analysis (Utermöhl, 1958). Enumeration and identification of algae were performed under an Olympus BX 51 compound microscope, equipped with water immersion lenses and a phase contrast attachment. Algal species were identified according to the most updated literature. Taxonomy of algae follows Guiry and Guiry (2016). Phytoplankton biomass was calculated from biovolume estimations (Wetzel and Likens, 2000; Sun and Liu, 2003). Species were grouped in FGs according to Reynolds et al. (2002) and Padisák et al. (2009).

\section{Physical and chemical analyses}

Sampling for chemical analyses and measurement of physical variables was carried out contemporary to phytoplankton collection. Conductivity (EC), redox potential (ORP), $\mathrm{pH}$ and water temperature $(T)$ were measured at $1 \mathrm{~m}$ intervals using YSI 6600 multi-parameter water quality sonde (YSI Inc., Ohio, USA). Water transparency was measured on each sampling date using a Secchi disc. Dissolved inorganic nitrogen (DIN) concentrations were considered as the sum of the nitratenitrogen $\left(\mathrm{NO}_{3}-\mathrm{N}\right)$, nitrite-nitrogen $\left(\mathrm{NO}_{2}-\mathrm{N}\right)$ and ammonium-nitrogen $\left(\mathrm{NH}_{4}-\mathrm{N}\right)$. Concentrations of soluble reactive phosphorus (SRP), $\mathrm{NO}_{3}-\mathrm{N}, \mathrm{NO}_{2}-\mathrm{N}$ and $\mathrm{NH}_{4}-\mathrm{N}$ were spectrophotometrically determined using samples collected at 1,5 and $10 \mathrm{~m}$ of depth in the first station and 1,5 and $15 \mathrm{~m}$ in the second and in the third stations (corresponding to the surface, middle and deep parts of the reservoir) according to Strickland and Parsons (1972) and Technicon Industrial Methods (1977a, 1977b). Samplings were collected at 1,5 and $\sim 1 \mathrm{~m}$ from the bottom of each station when the depth at these stations was low. The euphotic zone $\left(z_{\mathrm{eu}}\right)$ was calculated as 2.7 times of Secchi depth (Cole, 1994). The depth of the mixing layer $\left(z_{\text {mix }}\right)$ was estimated from individual temperature profiles in all the stations. Mixed layer to euphotic zone $\left(z_{\mathrm{mix}} / z_{\mathrm{eu}}\right)$ ratio was used as a measure of light availability in the mixed layer (Jensen et al., 1994).

\section{Data analysis}

An ANOVA (analysis-of-variance) test was applied to data for determining the statistical differences in species richness, biomass and the main physical and chemical parameters among sampling stations, sampling depths and seasons using SPSS 20.0 software. Pearson's correlations between the selected physical and chemical parameters and species richness and biomass values were also calculated using the SPSS 20.0 software. Redundancy analysis (RDA) was carried out using CANOCO software (Ter Braak and Smilauer, 2002). To determine the relationship between the biomass of the FGs, sampling period and environmental variables, RDA was carried out on the log-normal transformed abundance data. Statistical significance of the environmental predictor variables was assessed by 999 restricted Monte Carlo permutations.

\section{Results}

\section{Environmental parameters}

The maximum inflow $\left(5 \times 10^{3} \mathrm{~m}^{3} \cdot \mathrm{s}^{-1}\right)$ to the reservoir occurred in spring and the minimum $\left(25 \mathrm{~m}^{3} \cdot \mathrm{s}^{-1}\right)$ in the fall. This seasonal difference in water inflow and the summer use of water for irrigation purposes caused the water level to decrease by $10 \mathrm{~m}$. Winter and spring represent the filling period of the reservoir, which, with the beginning of May, starts emptying due to the irrigation demand and increased evaporation losses. From the middle of September, ending agriculture needs, the reservoir fills up again.

Temperature profiles showed that the water column was stratified from April to August 2007 ( $f=2.68, n=88$, $P<0.05)$ and from April to September $2008(f=2.5$, $n=111, P<0.05)$ during the study period. From spring to mid-summer, the availability of light was high in the mixing zone. After the break down of the thermocline, values of $z_{\mathrm{mix}} / z_{\mathrm{eu}}>1.7$ were recorded in the first and in the second station and $>2$ in the third station (Fig. 2). $z_{\text {mix }} / z_{\text {eu }}$ values were significantly different among seasons $(f=3.61, n=72, P<0.05)$ and were significantly different in the third station compared with the others $(f=10.33$, $n=72, P<0.05)$.

Values of measured physical and chemical variables are shown in Table 1. SRP values were slightly higher in winter and significantly different along the vertical profile 
St.1

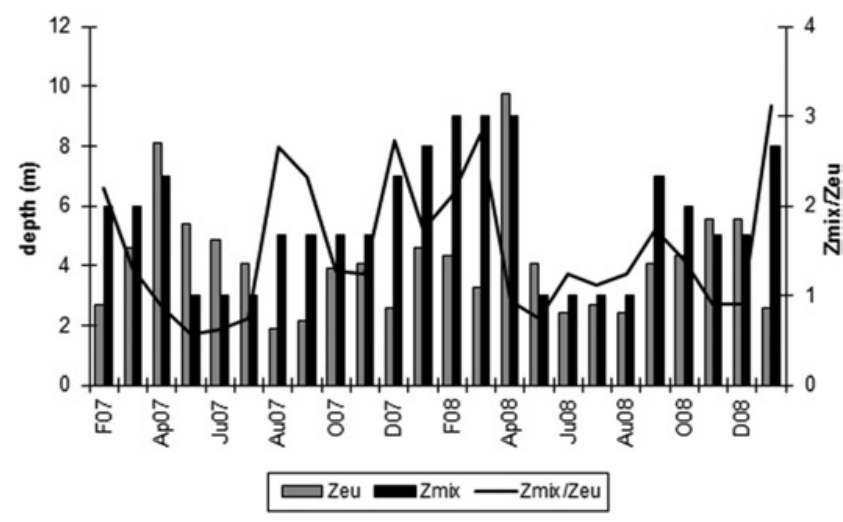

St.2

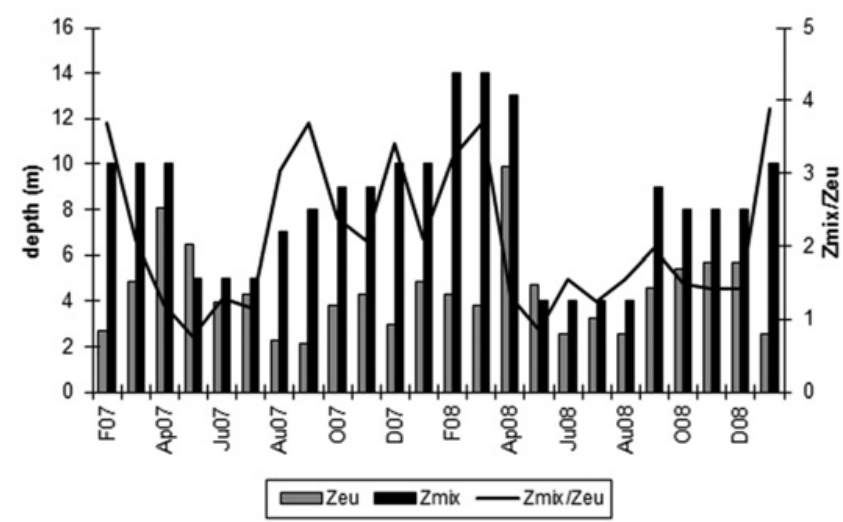

St.3

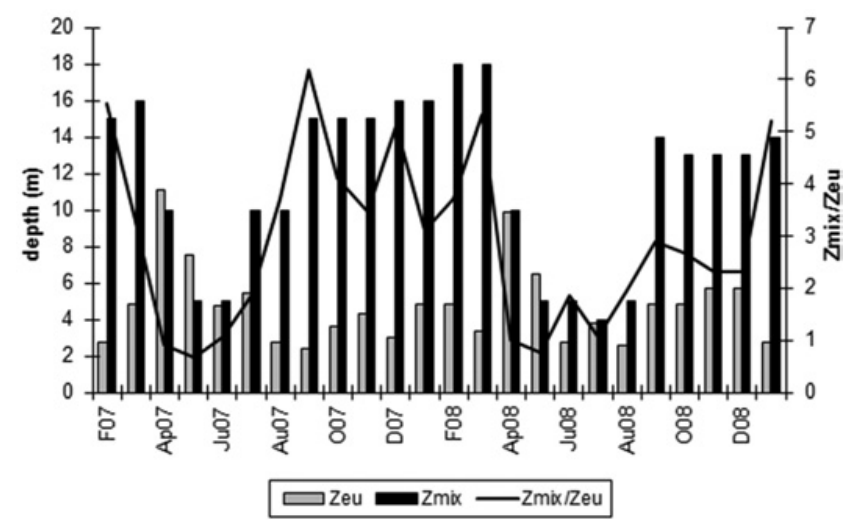

Fig. 2. Seasonal variation of the mixing zone $\left(z_{\text {mix }}\right)$, euphotic zone $\left(z_{\mathrm{eu}}\right)$, and the $z_{\mathrm{mix}} / z_{\mathrm{eu}}$ ratio in the İkizcetepeler reservoir.

as a result of high concentrations in 10 and $15 \mathrm{~m}$ from June to July, $2007(f=26.28, n=18, P<0.05)$ and from October to December, $2007(f=234.31, n=27, P<0.05)$. However, no significant differences have been found among sites $(P>0.05)$. DIN values in 2007 were higher than the values in 2008 and no significant differences were recorded at the different depth, except in summer 2008 when highest concentrations were measured at $1 \mathrm{~m}$ and lowest at $5 \mathrm{~m}$. More in general, environmental variables were significantly different among seasons $(P<0.05)$ and no significant differences were found among sites or sampling depth $(P>0.05)$ in EC, $\mathrm{pH}$ and ORP values.

\section{Phytoplankton structure}

A total of 174 taxa belonging to 25 FGs were identified in the reservoir. Pearson's correlation coefficients between selected environmental variables and, biomass and species richness are shown in Table 2. Species richness ranged from 32 to 83 and was significantly different among seasons $(f=106.47, n=528, P<0.05)$. No significant differences were found among sites or sampling depth $(P>0.05)$.

Phytoplankton total biomass ranged from 0.14 to 43 mg. $\mathrm{L}^{-1}$ (Fig. 3). The highest values were recorded between 2 and $10 \mathrm{~m}$ during summer 2007 and in May 2008 . The high biomass between July and September 2007 was due to species with large size belonging to the FGs $\mathbf{J}$ (e.g., Scenedesmus ellipticus Corda, Desmodesmus spp., Pseudopediastrum boryanum (Turpin) Hegewald, Monactinus spp.) and $\mathbf{P}$ (e.g., Aulacoseira granulata (Ehrenberg) Simonsen, Aulacoseira subarctica (Müller) Haworth). Biomass values in August 2007 and May 2008 were different along the vertical profile $(f=7.97, n=26$, $P<0.05$ and $f=4.37, n=36, P<0.05$, respectively). Biomass values were significantly different among seasons $(f=42.65, n=528, P<0.01)$ and different between first and third stations $(f=2.84, n=528, P<0.05)$.

\section{Seasonal dynamics and vertical distribution of phytoplankton ecological groups}

The temporal distribution of main phytoplankton strategies was shown (Fig. 4). In particular, C-strategists were dominant in winter and spring, followed by $\mathrm{S}$-strategists in mid-summer and by $\mathrm{R}$-strategists after the breaking of the thermocline. C-strategists were also present with representatives of the codon $\mathbf{B}$ (mainly Stephanodiscus neoastraea Håkansson and Hickel), during mid-summer and fall in both years when S- and R-strategists dominated.

Nine FGs constituted $>20 \%$ of the total biomass in at least one sample and $\mathbf{B}, \mathbf{Y}, \mathbf{J}$ and $\mathbf{P}$ were the main FGs (Fig. 5). Three different periods could be identified, based on differences in morphological variability and $z_{\text {mix }} / z_{\text {eu }}$ ratio (Table 3 ).

Period I (Nov.-Apr. 2007-2008 and May 2008): C-strategists, belonging to FGs Y (Cryptomonas ovata Ehrenberg and C. caudata Massart) and B (Lindavia ocellata (Pantocsek) Nakov et al. and S. neoastraea), dominated phytoplankton assemblage in this period accompanied by small flagellates belonging to codon X2 (Cryptomonas pyrenoidifera Geitler and Plagioselmis nannoplanctica (Skuja) Novarino, Lucas and Morrall) and $\mathbf{C}$ (Cyclotella meneghiniana Kützing).

During November to March 2007 and 2008, vertical distribution of the two dominant coda was generally 
Table 1. The mean, minimum and maximum values of physical and chemical variables measured at the sampling sites in the İkizcetepeler reservoir water during the study period.

\begin{tabular}{|c|c|c|c|c|c|c|}
\hline \multirow[b]{2}{*}{ Variable } & \multicolumn{2}{|c|}{ Station 1} & \multicolumn{2}{|c|}{ Station 2} & \multicolumn{2}{|c|}{ Station 3} \\
\hline & Mean & Min.-Max. & Mean & Min.-Max. & Mean & Min.-Max. \\
\hline Water temperature $\left({ }^{\circ} \mathrm{C}\right)$ & 15.8 & $5.1-26.3$ & 15.8 & $4.8-26.5$ & 15.9 & $4.7-26.8$ \\
\hline $\mathrm{pH}$ & 8.72 & $7.43-9.9$ & 8.74 & $7.12-9.89$ & 8.79 & $7.1-9.86$ \\
\hline Conductivity $\left(\mu \mathrm{S} . \mathrm{cm}^{-1}\right)$ & 338 & $244-403$ & 337 & $245-401$ & 338 & $247-399$ \\
\hline Redox potential (mV) & 104.8 & $-19.2-205.8$ & 102.3 & $-21.8-199$ & 104.4 & $-28.9-202.3$ \\
\hline Secchi disc $(\mathrm{cm})$ & 153.9 & $70-360$ & 162.5 & $80-365$ & 177 & $90-410$ \\
\hline Zmix/Zeu & 1.52 & $0.56-3.11$ & 2.11 & $0.77-3.89$ & 2.89 & $0.66-6.17$ \\
\hline Dissolved inorganic nitrogen $\left(\mathrm{mg} . \mathrm{L}^{-1}\right)$ & 0.18 & $0.1-0.26$ & 0.17 & $0.09-0.25$ & 0.19 & $0.09-0.31$ \\
\hline Soluble reactive phosphorus (mg. $\left.\mathrm{L}^{-1}\right)$ & 0.025 & $0.01-0.05$ & 0.02 & $0.02-0.05$ & 0.02 & $0.006-0.06$ \\
\hline
\end{tabular}

Table 2. Pearson's correlation coefficients between selected environmental variables and, biomass and species richness $(* P<0.05 ; * * P<0.01)$.

\begin{tabular}{lll}
\hline & \multicolumn{1}{c}{ Biomass } & Species richness \\
\hline$z_{\text {mix }} / z_{\text {eu }}$ & $-0066(n=72)$ & $-034^{* *}(n=72)$ \\
Temperature & $0.42^{* *}(n=528)$ & $0.67^{* *}(n=528)$ \\
Dissolved inorganic nitrogen & $0.15^{* *}(n=288)$ & $0.22^{* *}(n=288)$ \\
Soluble reactive phosphorus & $0.11^{*}(n=288)$ & $0.36^{* *}(n=288)$ \\
\hline
\end{tabular}

homogeneous as a result of mixing. However, cryptophyceans were more abundant in deeper waters (below $1 \mathrm{~m}$ ) from December 2007 to February 2008. With the beginning of April, the reservoir was thermally stratified and $z_{\mathrm{mix}} / z_{\mathrm{eu}}$ ranged between 0.74 and 1.32 as a result of both increasing euphotic depth and decreasing mixing depth. Phytoplankton biomass increased in parallel to water column stability and highest biomass $(53-97 \%$ of the total phytoplankton biomass) values were recorded in May 2008 as a result of the dominance of large C. ovata (codon $\mathbf{Y})$.

Period II (May. 2007, Jun.-Jul. 2007-2008 and Aug. 2008): During those periods, reservoir had a sufficient depth to maintain its thermocline, and both C- and Sstrategists were important. Groups B (S. neoastraea) and $\mathbf{J}$ (S. ellipticus, Desmodesmus spp., P. boryanum, Monactinus spp., Coelastrum astroideum De Notaris) prevailed in both years. Their biomass was high (mean 44 and $52 \%$ of the biomass, respectively) and they were abundant through the water column. Members of codon $\mathbf{J}$ mainly distributed between 2 and $10 \mathrm{~m}$ in May 2007, and 1 and $4 \mathrm{~m}$ in June and July 2008, while, abundance of codon B increased between 5 and $10 \mathrm{~m}$ in August 2008 .

The contribution of the codon $\mathbf{F}$ (Sphaerocystis planctonica (Korshikov) Bourrelly, Oocystis spp.) was also important in these periods. This group was found between surface and $4 \mathrm{~m}$ in July 2008. Also large thecate dinoflagellates (Peridinium cinctum (Müller) Ehrenberg, Peridiniopsis spp.) (codon Lo) were important components of phytoplankton. Their abundance was high near the surface and decreased with increasing depth. In particular, they constituted $65 \%$ of the biomass in the surface waters at the first station, $31 \%$ at the second station and $20 \%$ at the third station in July 2007. Moreover, the benthic cyanobacterium Oscillatoria limosa Agardh ex Gomont (codon Tc) was only found in the deeper layers of the first station and contributed the $38 \%$ of the total biomass in May 2007.

Period III (Aug. 2007 and Sep.-Oct. 2007-2008): These periods were characterized by the breaking down of the thermocline. As a consequence, in August 2007, an increase was observed in $z_{\text {mix }} / z_{\mathrm{eu}}$ values $(>3.5$ ). Thermocline disruption in September 2008 brought $z_{\text {mix }} /$ $z_{\mathrm{eu}}$ values to 2.7. After this change in the underwater light availability, the dominance of shape-adapted species of codon $\mathbf{P}$ (A. granulata, A. subarctica) was observed both in 2007 and 2008. This codon was replaced by codon $\mathbf{J}$ (P. boryanum, Monactinus spp.) in September 2007 and by codon B (S. neoastraea) in October 2008. In August 2007, the abundance of codon $\mathbf{P}$ increased along with depth. Members of codon Lo ( $P$. cinctum and Entzia acuta (Apstein) Lebour) were also abundant (17-34\% of the total biomass) at $2 \mathrm{~m}$ in the riverine and transition zones and at $5 \mathrm{~m}$ in the lacustrine station in September and October 2008.

\section{Environmental parameters and phytoplankton FGs}

To analyze the relationship between phytoplankton distribution and environmental variables, we performed a RDA using biomass values of the nine dominant FGs. RDA was performed initially on the whole environmental and FGs datasets. Forward selection indicated that four of the 12 environmental variables made significant contribution to the variance in the FGs data. The results of RDA using only these four variables are illustrated (Fig. 6). The eigenvalues of RDA axis $1(0.38)$ and axis $2(0.04)$, account for $41.8 \%$ of the cumulative variance in the FGs data. The FGs - environmental correlations of RDA axis 1 and 2 are high and the first two axis account for $94.4 \%$ of the variance in the FGs - environmental relationships. Period I is positively correlated with $\mathbf{Y}, \mathbf{B}, \mathbf{C}, \mathbf{X} 2, z_{\text {mix }} / z_{\mathrm{eu}}$ and SRP, while Period II is positively correlated with Te, F, J, Lo, temperature and DIN. Period III is positively correlated with $\mathbf{J}, \mathbf{L o}, \mathbf{P}$, temperature and $z_{\text {mix }} / z_{\mathrm{eu}}$.

\section{Discussion}

Reservoirs in the Mediterranean area are regulated systems constructed to provide water for drinking and 


\section{St.1}

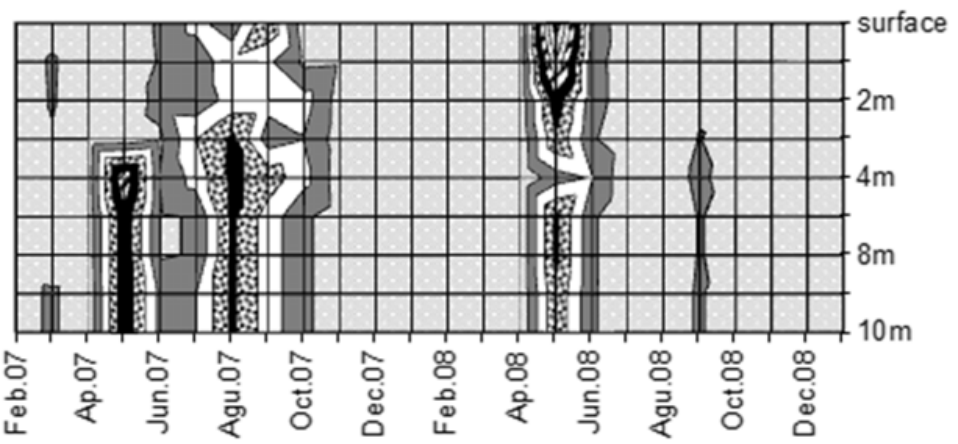

St.2

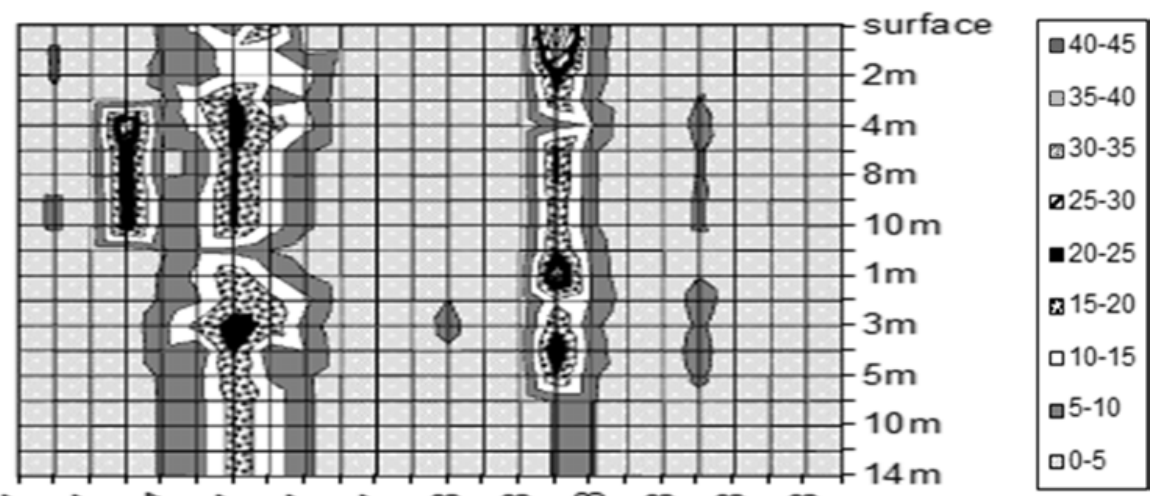

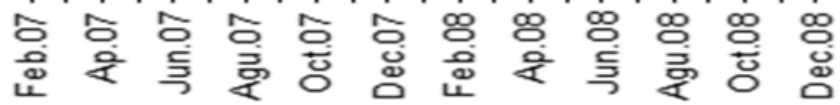

\section{St.3}

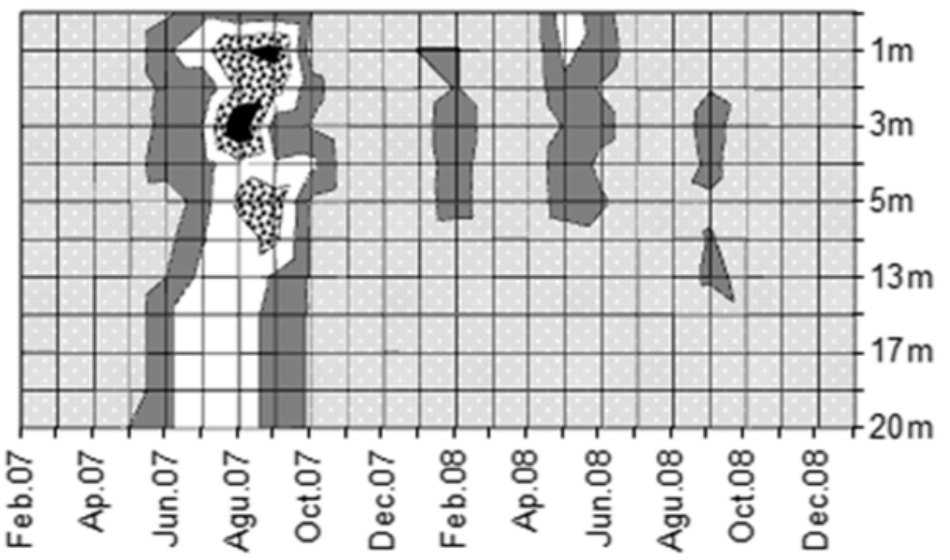

Fig. 3. Spatial and temporal variations of phytoplankton biomass $\left(\mathrm{mg} . \mathrm{L}^{-1}\right)$ in the İkizcetepeler reservoir.

irrigation during the summer dry periods, which characterize Mediterranean climate (Naselli-Flores, 2014). Their (over-)exploitation during summer when precipitation is scarce, reduce water level, which in turns, alter the physical structure of lakes, disrupting stratification patterns (Rimmer et al., 2011). Ikizcetepeler reservoir is a warm monomictic Mediterranean lake, used for irrigation and providing drinking water to Balıkesir city. Depending on the water demand and summer drought, its depth quickly decreases during summer, and consequently midsummer breakdown in the thermocline is observed. In the studied period, the breaking down of the thermocline was followed by a consistent increase in $z_{\mathrm{mix}} / z_{\text {eu. }}$. The effects of $z_{\text {mix }} / z_{\text {eu }}$ ratio on phytoplankton assemblages were reported in Mediterranean region (Naselli-Flores and Barone, 1998, 2000, 2007; Naselli-Flores, 2000; Hoyer et al., 2009; Becker et al., 2010). The ratio is a good descriptor of the underwater light climate experienced by phytoplankton and its values can be related to the morphological structure of phytoplankton assemblage, 
St.1
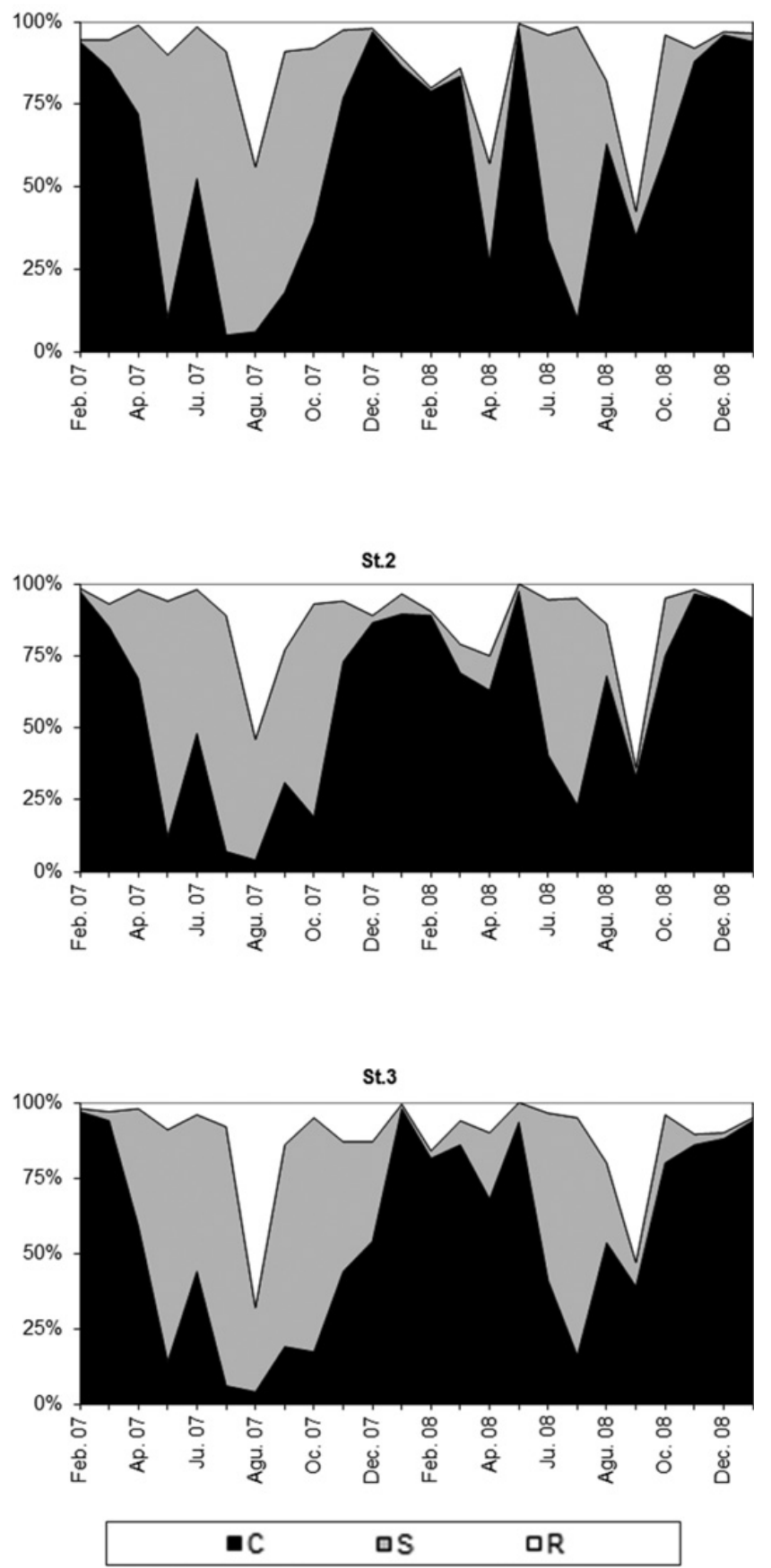

Fig. 4. Relative contribution to total biomass of the three survival strategies of phytoplankton $(\mathrm{C}, \mathrm{S}, \mathrm{R})$ in the three sampling sites.

especially in the upper part of the trophic spectrum (Naselli-Flores, 2000; Naselli-Flores and Barone, 2007). The influence of nutrients on the structure of phytoplankton appears to be more important in the lower part of the trophic spectrum (Naselli-Flores and Barone, 1998; Naselli-Flores, 2000).

Morphological features of shape and size represent the starting point to fully understand the relationships between phytoplankton and its environment (NaselliFlores and Barone, 2011). Nutrients (e.g., Kagami and
Urabe, 2001) and light availability (e.g., O'Farrell et al., 2007) are the most important factors promoting a shape variation in the dominant morphology of phytoplankton (Naselli-Flores and Barone, 2007). In particular, eutrophic and hypertrophic conditions offer a good opportunity to investigate the effect of light availability since nutrient limitation is unlike to occur. Moreover, elongated shapes and buoyant cyanobacteria were most common in those environments characterized by stronger light limitation, as already reported for other Mediterranean reservoirs (Naselli-Flores and Barone, 2007; Naselli-Flores, 2014). On the other hand, as shown by Morabito et al. (2007), efficiency in nutrient uptake is largely depends on $\mathrm{S} / \mathrm{V}$ (surface/volume) ratio. High values of this ratio are common in small-sized organisms and are generally related to a better nutrient flux per unit volume. Thus, efficiency in nutrient uptake is a major force shaping phytoplankton morphology in oligotrophic and mesotrophic environments (Naselli-Flores et al., 2007). In Mediterranean reservoirs, generally, the $\mathrm{C} \rightarrow \mathrm{S} \rightarrow \mathrm{R}$ successional pattern was observed among phytoplankton assemblage (Padisák et al., 2010; Rigosi and Rueda, 2012). In the higher part of the trophic spectrum, this succession pattern was obvious, where $z_{\text {mix }} / z_{\text {eu }}<3.5$ (Naselli-Flores, 2014). In mesotrophic İkizcetepeler reservoir, changes in $z_{\text {mix }} / z_{\text {eu }}$ regulated this successional pattern, whereas high $z_{\text {mix }} / z_{\text {eu }}$ selected C and $\mathrm{R}$ strategists and low $z_{\text {mix }} / z_{\text {eu }}$ selected $\mathrm{S}$ strategists. Although this pattern was recorded during the study period, C strategists (especially diatom $S$. neoastraea and cryptophytes $C$. ovata and $C$. caudata) were almost always present. This was also observed in other mesotrophic Mediterranean reservoirs, whereas C-strategists Cyclotella spp. was typical representatives of the assemblages (Caputo et al., 2008; Çelekli and Öztürk, 2014).

Considering the concentrations of dissolved nutrients and the algal requirements based on half-saturations for growth, phytoplankton in the studied reservoir did not experience nutrient limitation since the values were always above the required levels for phytoplankton growth saturation (Reynolds, 1997). However, RDA analysis supports the importance of DIN and SRP for phytoplankton assemblages. Particularly, hypolimnetic SRP concentrations were always high and allegedly due to the internal loading. Similar patterns were observed in Lake Kinneret (Hambright et al., 2004) and Lake Arancio (NaselliFlores, 2014). Biomass and species richness also increased in parallel with the increase in temperature, DIN and SRP values. Especially, biomass values of 2007 were higher than values of 2008 , as a result of higher values of DIN in 2007. In May 2008, the highest phytoplankton biomass values were recorded due to an increase of $C$. ovata and mainly concentrated between 5 and $10 \mathrm{~m}$. The maximum biomass of cryptophytes occupied deeper depths, as we also observed, where their low light requirement is satisfied (Graham and Wilcox, 2000; Ptacnik et al., 2003; Longhi and Beisner, 2009).

Lakes and reservoirs with euphotic depth almost equal to mixing depth are generally characterized by a DCM (deep chlorophyll maximum) and phytoplankton 


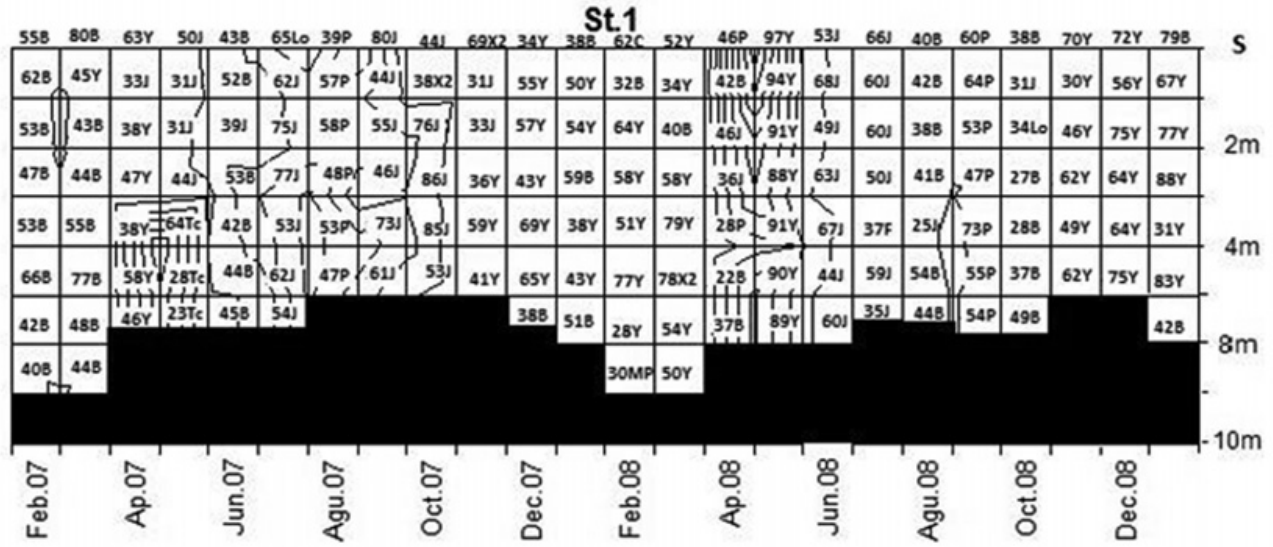

St.2

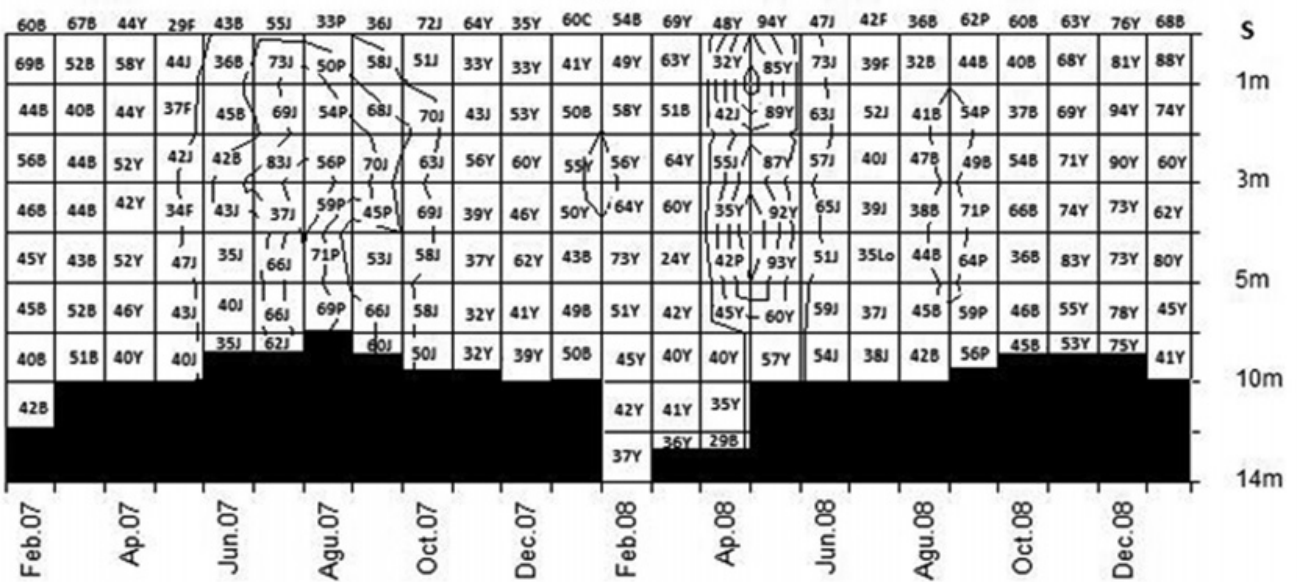

St. 3

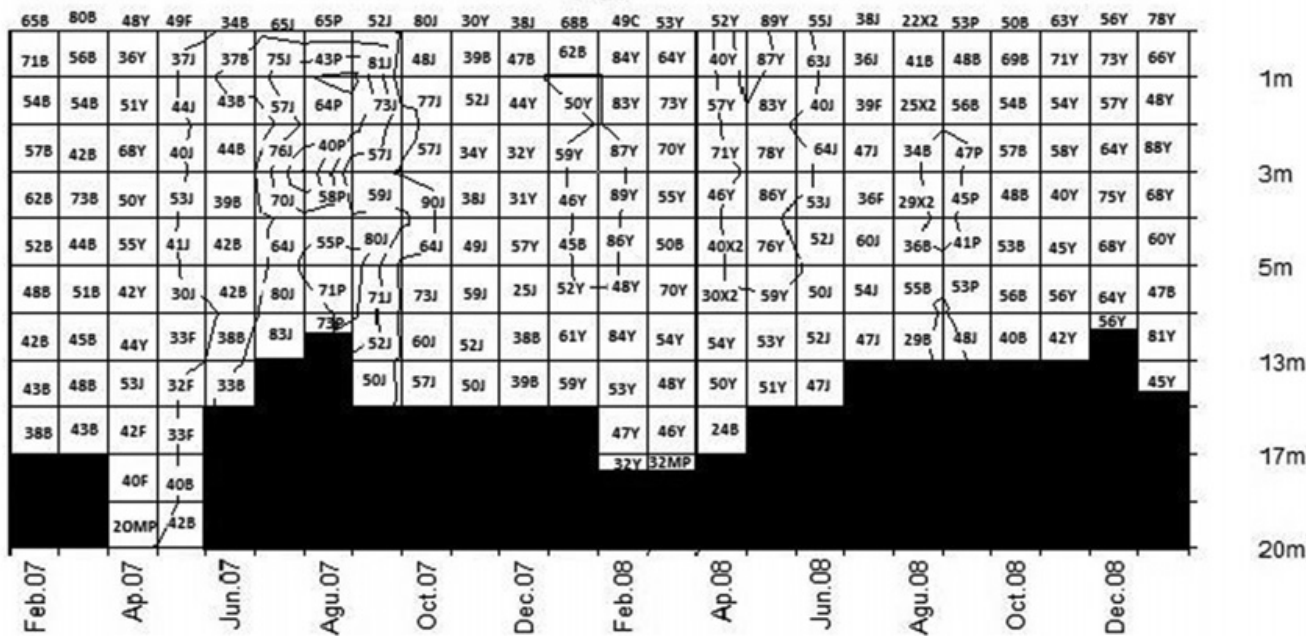

Fig. 5. Relative frequency of dominant phytoplankton FGs (\%) along the vertical gradients in the three sampling sites. Dark area indicates the bottom.

taxonomic groups (chlorophytes, cryptophytes and diatoms) in such systems show heterogeneous vertical distribution patterns (Effler and O'Donnell, 2001; Hamilton et al., 2010). On the other hand, more turbid ones where mixing depth deeper than euphotic depth, promoted the aggregates of positively buoyant cyanobacteria in the upper layers of the water column (Moreno-Ostos et al., 2006). Moreover, Longhi and Beisner (2009) suggested that vertical variation of phytoplankton taxonomic groups was related mainly to epilimnetic water color and total phosphorus concentration. They observed that darker lakes with more stained waters have more 
Table 3. Main species and morphology-based phytoplankton groups in the three periods of the İkizcetepeler reservoir.

\begin{tabular}{|c|c|c|c|c|}
\hline Periods & Dominant taxa & Accompanying taxa & $\begin{array}{l}\text { Morphology-based } \\
\text { (for dominant taxa) }\end{array}$ & $Z_{\text {mix }} / Z_{\text {eu }}($ mean $)$ \\
\hline Period I & $\begin{array}{c}\text { Stephanodiscus neoastraea }(\mathbf{B}) \\
\text { Lindavia ocellata }(\mathbf{B}) \\
\text { Cryptomonas ovata }(\mathbf{Y}) \\
\text { Cryptomonas caudata }(\mathbf{Y})\end{array}$ & $\begin{array}{c}\text { Cyclotella meneghiniana }(\mathbf{C}) \\
\text { Cryptomonas pyrenoidifera }(\mathbf{X 2}) \\
\text { Plagioselmis nannoplanctica }(\mathbf{X 2})\end{array}$ & C-strategists & 2.39 \\
\hline Period II & $\begin{array}{c}\text { S. neoastraea }(\mathbf{B}) \\
\text { Scenedesmus ellipticus }(\mathbf{J}) \\
\text { Pseudopediastrum boryanum }(\mathbf{J}) \\
\text { Desmodesmus spp. }(\mathbf{J}) \\
\text { Monactinus spp. }(\mathbf{J}) \\
\text { Coelastrum astroideum }(\mathbf{J})\end{array}$ & $\begin{array}{c}\text { Sphaerocystis planctonica }(\mathbf{F}) \\
\text { Oocystis spp. }(\mathbf{F}) \\
\text { Peridinium cinctum }(\mathbf{L o}) \\
\text { Peridiniopsis spp. }(\mathbf{L o}) \\
\text { Oscillatoria limosa }(\mathbf{T c})\end{array}$ & C- and S-strategists & 1.46 \\
\hline Period III & $\begin{array}{c}\text { P. boryanum }(\mathbf{J}) \\
\text { Monactinus spp. }(\mathbf{J}) \\
\text { A. granulata }(\mathbf{P}) \\
\text { A. subarctica }(\mathbf{P}) \\
\text { S. neoastraea }(\mathbf{B})\end{array}$ & $\begin{array}{l}\text { P. cinctum }(\mathbf{L o}) \\
\text { Entzia acuta }(\mathbf{L o})\end{array}$ & C-, S- and R-strategists & 2.76 \\
\hline
\end{tabular}

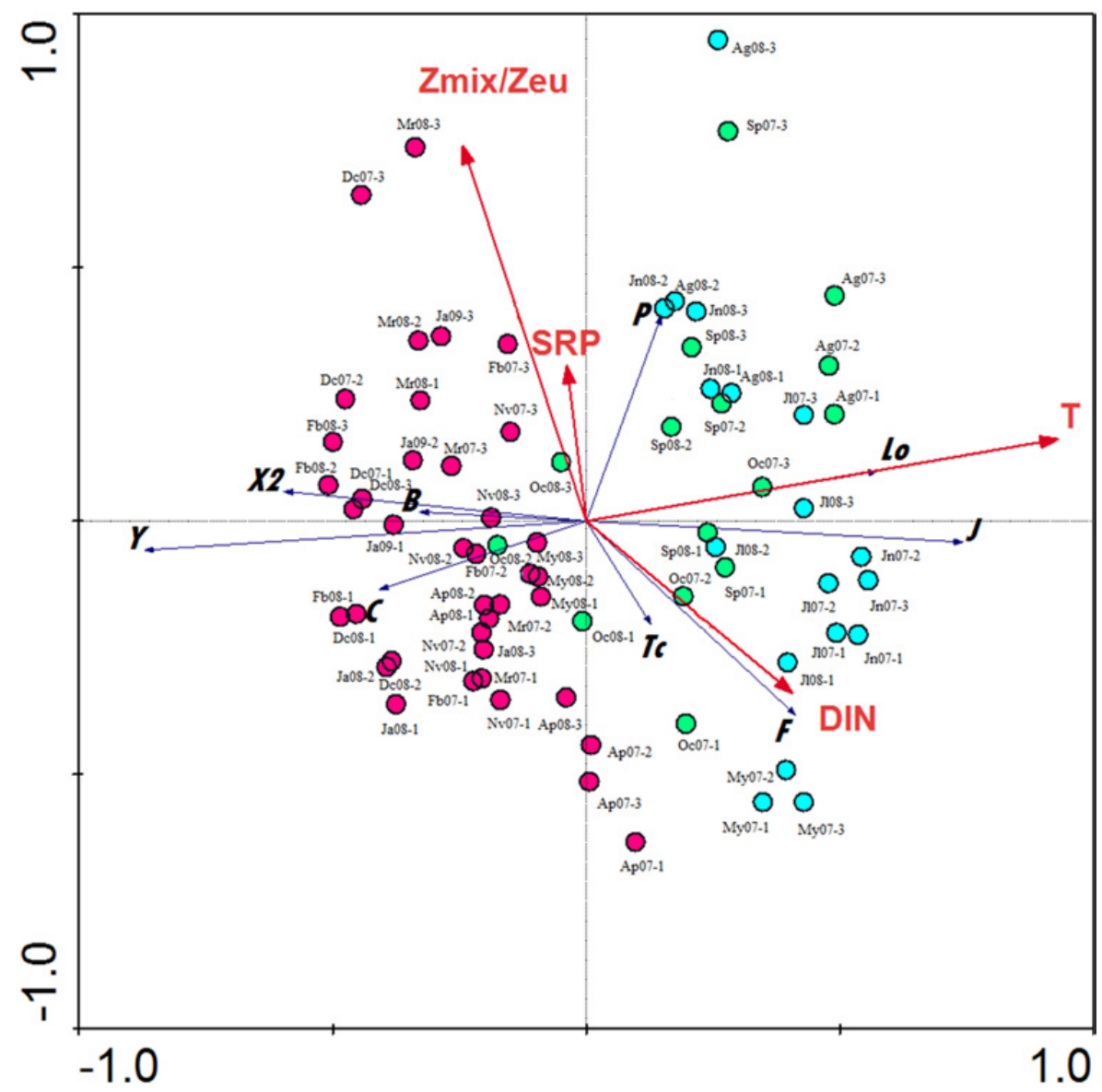

Fig. 6. Ordination of the samples corresponding to the different sampling periods, scores of phytoplankton biomass by FGs and environmental variables, along the redundancy analysis axes. Environmental variables: T, water temperature; SRP, soluble reactive phosphorus; DIN, dissolved inorganic nitrogen; $z_{\mathrm{mix}} / z_{\mathrm{eu}}$, ratio of mixing and euphotic layers. Sampling periods: first character corresponds to sampling months and years, and subsequent ones to stations (red, Period I; blue, Period II; green, Period III).

stable water columns. These studies revealed that deep lakes and reservoirs in the lower part of the trophic spectrum need a higher sampling effort compared with morphometrically similar eutrophic and hypertrophic water bodies, where sub-superficial samples may be considered representative of the structure of the whole phytoplankton assemblage. Phytoplankton vertical heterogeneity has often been undervalued as it was expressed only as the bulk chlorophyll $a$ concentration, total biomass or phytoplankton taxonomic groups (Longhi and Beisner, 2009; 
Hamilton et al., 2010). Previously, Becker et al. (2009b) showed diel variation of phytoplankton FGs in a tropical reservoir during stratification period; however, long-term vertical variation of $\mathrm{FGs}$ was ignored. Even though Crossetti and Bicudo (2008) considered five different depths in a long-term period, their study mainly focused on three different water phases during 7 years, rather than the vertical variation of FGs. In this respect, our results provide evidence on vertical heterogeneous distribution of phytoplankton FGs in mesotrophic Mediterranean reservoir, allowing for a deeper understanding of the role of different groups in such systems.

Generally, vertical heterogeneity of FGs $\mathbf{J}, \mathbf{F}, \mathbf{T c}$, Lo and $\mathbf{B}$ was observed as a result of vertical heterogeneity of water temperature, high values of DIN in surface waters, low values of $z_{\mathrm{mix}} / z_{\mathrm{eu}}$ and cell sedimentation loss during stratification period. These results revealed that phytoplankton showed the most pronounced vertical heterogeneity during stratification. Previous studies also have shown that the thermal structure of the water column should influence vertical distribution of phytoplankton by affecting the average light environment, nutrient availability and cell sedimentation loss (Reynolds, 1984; Diehl et al., 2002; Longhi and Beisner, 2009). Although the results showed SRP values were higher in the bottom layers in June and July 2007, there was no effect on the vertical heterogeneity of FGs. Groups $\mathbf{J}, \mathbf{F}, \mathbf{T c}$ and Lo include organisms (S-strategists), mainly represented by colonial chlorophytes, dinoflagellates and filamentous cyanobacteria. Consistently with theoretical patterns, O'Farrell et al. (2007) found a prevalence of small unicellular, non-flagellated organisms, thin filaments or small tabular colonies in light limited environments, whereas flagellated forms and larger organisms prevailed in well illuminated ones. Increased dimensions of Chlorophyta in mesotrophic environments, where the light limitation is not severe, may allow more rapid movements in the water column to optimize nutrient exploitation. In a study of 45 lakes in eastern Canada, chlorophytes showed the shallowest average peak depth and the most heterogeneous distribution of all groups and their heterogeneity were greatest in lakes with clear, unproductive transparent waters (Longhi and Beisner, 2009). Becker et al. (2009b) also found the dominance of codon $\mathbf{F}$ in the epilimnion of stratified meso-eutrophic reservoir. Similar results were observed in our study: coda $\mathbf{F}$ and $\mathbf{J}$ mainly dominated above $5 \mathrm{~m}$ where high DIN and low $z_{\text {mix }} / z_{\text {eu }}$ values were observed. With regard to large dinoflagellates (codon Lo), they were found near the surface in the stratification period. Reynolds et al. (2002) stated that members of large dinoflagellates (codon Lo) are usually found in summer epilimnia in mesotrophic lakes with segregated nutrients and without prolonged or deep mixing. They exhibit motility, which enables them to maintain their position through the water column to suffice light requirements (Naselli-Flores and Barone, 2000). Darabă and Miron (2006) found that the density of $O$. limosa was minimum at 12:00 a.m. due to the high quantity of light in the study of Potoci Gulf - Bicaz Lake. Reynolds (1997) also stated that Oscillatoriales were typical of very turbid environments and low light conditions. In our study, the S-strategist $O$. limosa (codon $\mathbf{T c}$ ) was only found in the deeper parts of the reservoir at very low light conditions. During stratification, only the C-strategist $S$. neoastraea (codon B) showed a heterogeneous vertical distribution. Biomass of this group increased between 5 and $10 \mathrm{~m}$ in August 2008, and disappeared when the mixing event caused $z_{\mathrm{mix}} / z_{\mathrm{eu}}<2$. Similar results were reported from meso-oligotrophic reservoirs where diatom species occupied deeper depth when stratification became stronger (Moreno-Ostos et al., 2006). Since diatoms cannot actively regulate their position in the water column, they tend to sink under calm conditions. As a consequence, codon B aggregate on the metalimnion in well-stratified waters, where the denser layer of water slows down their sinking (Reynolds, 1984).

Vertical heterogeneity of phytoplankton was also observed during mixing in the FGs Lo, $\mathbf{P}$ and $\mathbf{Y}$. Members of codon $\mathbf{Y}$ were found below $1 \mathrm{~m}$ between December 2007 and February 2008, probably because of the higher light availability in winter season. In August 2007, after the disruption of the thermocline and the occurrence of higher $z_{\text {mix }} / z_{\text {eu }}$, the abundance of codon $\mathbf{P}$ increased with increasing depth. Their elongated shape and shade adaptations (Silva et al., 2005) are actually useful for their survival in darker conditions. This kind of diatom-dominated deep maxima was also observed in other temperate lakes (Fahnenstiel and Glime, 1983; Barbiero and Tuchman, 2001; Camacho et al., 2001). With regard to codon Lo, they were abundant between 2 and $5 \mathrm{~m}$ in September and October 2008. Huszar et al. (2003) indicated that decreasing temperature and deepening of mixing zone are unfavorable for Lo dominance; however, the relatively high temperature recorded in those months in the studied reservoir may favor their high biomass values.

\section{Conclusion}

In conclusion, nutrient dynamics, temperature and light availability were mainly driven by the water circulation patterns, governing the phytoplankton morphological variability $(\mathrm{C} \rightarrow \mathrm{S} \rightarrow \mathrm{R})$ in İkizcetepeler reservoir. Nutrient availability and temperature constituted the main environmental constraints influencing phytoplankton dynamics, while $z_{\text {mix }} / z_{\text {eu }}$ ratio played a secondary role. A similar conclusion for mesotrophic lakes was achieved by NaselliFlores (2000) by studying 21 Sicilian man-made lakes. Despite the variations in $z_{\text {mix }} / z_{\text {eu }}$ ratio as a result of stratification versus mixing events and water withdrawal, C-strategists were typical representatives of phytoplankton assemblage.

Similar to temporal distribution, vertical heterogeneity of phytoplankton was affected by nutrients (especially DIN values), temperature and $z_{\text {mix }} / z_{\text {eu }}$ values, which were mainly driven by the water circulation pattern. This study indicates that mixing and trophic state influence 
phytoplankton FG distribution throughout the entire water column and confirms our hypothesis.

Acknowledgements. The authors would like to thank Balıkesir University Research Foundation for financially supporting this research (Project number: 2007/18).

\section{References}

Albay M. and Akçaalan R., 2003. Factors influencing the phytoplankton steady state assemblages in a drinking-water reservoir (Ömerli reservoir, İstanbul). Hydrobiologia, 502, 85-95.

Barbiero R.M. and Tuchman M.L., 2001. Results from the EPA's biological open waters surveillance program of the Lauretian Great Lakes. II. Deep chlorophyll maxima. J. Great Lakes Res., 27, 155-166.

Becker V., Huszar V.L.M. and Crossetti L.O., 2009a. Responses of phytoplankton functional groups to the mixing regime in a deep subtropical reservoir. Hydrobiologia, 628, 137-151.

Becker V., Cardoso L.S. and Huszar V.L.M., 2009b. Diel variation of phytoplankton functional groups in a subtropical reservoir in southern Brazil during an autumnal stratification period. Aquat. Ecol., 43, 2285-2293.

Becker V., Caputo L., Ordóñez J., Marcé R., Armengol J., Crossetti L.O. and Huszar V.L., 2010. Driving factors of the phytoplankton functional groups in a deep Mediterranean reservoir. Water Res., 44, 3345-3354.

Borges P.A.F., Train S. and Rodrigues L.C., 2008. Spatial and temporal variation of phytoplankton in two subtropical Brazilian reservoirs. Hydrobiologia, 607, 63-74.

Camacho A., Erez J., Chicote A., Florin M., Squires M.M., Lehmann C. and Bachofen R., 2001. Microbial microstratification, inorganic carbon photoassimilation and dark carbon fixation at the chemocline of the meromictic Lake Cadagno (Switzerland) and its relevance to the food web. Aquat. Sci., 63, 91-106.

Caputo L., Naselli-Flores L., Ordonez J. and Armengol J., 2008. Phytoplankton distribution along trophic gradients within and among reservoirs in Catalonia (Spain). Freshwat. Biol., $53,2543-2556$.

Carlson R.E., 1977. A trophic state index for lakes. Limnol. Oceanogr., 22, 361-369.

Cole G.A., 1994. Textbook of Limnology, Waveland Press, Prospect Heights, Illinois.

Crossetti L.O. and Bicudo C.E.M., 2008. Phytoplankton as a monitoring tool in a tropical urban shallow reservoir (Garças Pond): the assemblage index application. Hydrobiologia, 610, 161-173.

Çelekli A. and Öztürk B., 2014. Determination of ecological status and ecological preferences of phytoplankton using multivariate approach in a Mediterranean reservoir. Hydrobiologia, 740, 115-135. doi: 10.1007/s10750-0141948-8.

Çelik K. and Sevindik T.O., 2011. The vertical and seasonal distribution of chlorophyll and main nutrients in a Mesotrophic Freshwater Reservoir. Int. J. Environ. Prot., 1, 9-14.

Darabă O.M. and Miron I., 2006. Nictemeral structure and dynamics of the phytoplankton in the Potoci Gulf-Bicaz
Lake. Analele Stiintifice ale Universitatii "AL. I. CUZA" Iaşi, s. Biologie animala, 52, 53-58.

Diehl S., Berger S., Ptacnik R. and Wild A., 2002. Phytoplankton, light, and nutrients in a gradient of mixing depths: field experiments. Ecology, 83, 399-411.

Effler S.E. and O'Donnell D.M., 2001. Resolution of spatial patterns in three reservoirs with rapid profiling instrumentation. Hydrobiologia, 450, 197-208.

Fahnenstiel G.L. and Glime J.M., 1983. Subsurface chlorophyll maximum and associated Cyclotella pulse in Lake Superior. Internationale Revue der Gesamten Hydrobiologie und Hydrographie, 68, 605-616.

Fonseca B.M. and Bicudo C.E.M., 2008. Phytoplankton seasonal variation in a shallow stratified eutrophic reservoir (Garças Pond, Brazil). Hydrobiologia, 600, 267-282.

Graham L.E. and Wilcox L.W., 2000. Algae, Prentice-Hall Inc., NJ.

Guiry M.D. and Guiry G.M., 2016. AlgaeBase. World-wide electronic publication, National University of Ireland, Galway. Accessed online 22 July 2016, http://www. algaebase.org

Hambright K.D., Eckert W., Leavitt P.R. and Schelske C.L., 2004. Effects of historical lake level and land use on sediment and phosphorus accumulation rates in Lake Kinneret. Environ. Sci. Technol., 38, 6460-6467.

Hamilton D.P., O'Brien K.R., Burford M.A., Brookes J.D. and McBride C.G., 2010. Vertical distributions of chlorophyll in deep, warm monomictic lakes. Aquat. Sci., 72, 295-307.

Hoyer A.B., Moreno-Ostos E., Vidal J., Blanco J.M., PalominoTorres R.L., Basanta A., Escot C. and Rueda F.J., 2009. The influence of external perturbations on the functional composition of phytoplankton in a Mediterranean reservoir. Hydrobiologia, 636, 49-64.

Huszar V.L.M., Kruk C. and Caraco N., 2003. Steady-state assemblages of phytoplankton in four temperate lakes (NE USA). Hydrobiologia, 502, 97-109.

ICOLD, 2007. Dams and the World's Water, an Educational Book that Explains How Dams Help to Manage the World's Water, VFC, Levallois-Perret-France.

Jensen P., Jeppesen E., Olrik K. and Kristensen P., 1994. Impact of nutrients and physical factors on the shift from cyanobacterial to chlorophyte dominance in shallow Danish lakes. Can. J. Fish. Aquat. Sci., 51, 1692-1699.

Kagami M. and Urabe J., 2001. Phytoplankton growth rate as a function of cell size: an experimental test in Lake Biwa. Limnology, 2, 111-117.

Karadžić V., Subakov-Simić G., Krizmanić J. and Natić D., 2010. Phytoplankton and eutrophication development in the water supply reservoirs Garaši and Bukulja (Serbia). Desalination, 255, 91-96.

Lindholm T., 1992. Ecological role of depth maxima of phytoplankton. Archiv für Hydrobiologie-BeiheftErgebnisse der Limnologie, 35, 33-45.

Longhi M.L. and Beisner B.E., 2009. Environmental factors controlling the vertical distribution of phytoplankton in lakes. J. Plankton Res., 31, 1195-1207. doi: 10.1093/plankt/ fbp065.

Morabito G., Oggioni A., Caravati E. and Panzani P., 2007. Seasonal morphological plasticity of phytoplankton in Lago Maggiore (N. Italy). Hydrobiologia, 578, 47-57. 
Moreno-Ostos E., Cruz-Pizarro L., Basanta-Alvés A., Escot C. and George D.G., 2006. Algae in the motion: spatial distribution of phytoplankton in thermally stratified reservoirs. Limnetica, 25, 205-216.

Naselli-Flores L., 2000. Phytoplankton assemblages in twenty-one Sicilian reservoirs: relationships between species composition and environmental factors. Hydrobiologia, 424, $1-11$.

Naselli-Flores L., 2014. Morphological analysis of phytoplankton as a tool to assess ecological state of aquatic ecosystems: the case of Lake Arancio, Sicily, Italy. Inland Waters, 4, 15-26.

Naselli-Flores L. and Barone R., 1998. Phytoplankton dynamics in two reservoirs with different trophic state (Lake Rosamarina and Lake Arancio, Sicily, Italy). Hydrobiologia, 369/370, 163-178.

Naselli-Flores L. and Barone R., 2000. Phytoplankton dynamics and structure: a comparative analysis in natural and manmade water bodies of different trophic state. Hydrobiologia, 438, 65-74.

Naselli-Flores L. and Barone R., 2007. Pluriannual morphological variability of phytoplankton in a highly productive Mediterranean reservoir (Lake Arancio, Southwestern Sicily). Hydrobiologia, 578, 87-95.

Naselli-Flores L. and Barone R., 2011. Fight on plankton! Or, phytoplankton shape and size as adaptive tools to get ahead in the struggle for life. Cryptogamie Algol., 32, 157-204.

Naselli-Flores L., Padisák J. and Albay M., 2007. Shape and size in phytoplankton ecology: do they matter? Hydrobiologia, $578,157-161$.

OECD (Organization for Economic Cooperation and Development), 1982. Eutrophication of waters. Monitoring, assessment and control. Final Report. OECD Cooperative Programme on Monitoring of Inland Waters (Eutrophication Control), Environment Directorate, OECD, Paris.

O'Farrell I., Izaguirre I. and de Tezanos Pinto P., 2007. Phytoplankton morphological response to the underwater light conditions in a vegetated wetland. Hydrobiologia, 578, 65-77.

Padisák J., Grigorszky I., Borics G. and Soróczki-Pintér E., 2006. Use of phytoplankton assemblages for monitoring ecological status of lakes within the Water Framework Directive: the assemblage index. Hydrobiologia, $553,1-14$.

Padisák J., Crossetti L.O. and Naselli-Flores L., 2009. Use and misuse in the application of the phytoplankton functional classification: a critical review with updates. Hydrobiologia, $621,1-19$.

Padisák J., Hajnal E., Naselli-Flores L., Dokulil M.T., Nõges P. and Zohary T., 2010. Convergence and divergence in organization of phytoplankton communities under various regimes of physical and biological control. Hydrobiologia, 639, 205-220.

Ptacnik R., Diehl S. and Berger S., 2003. Performance of sinking and nonsinking phytoplankton taxa in a gradient of mixing depths. Limnol. Oceanogr., 48, 1903-1912.

Rangel L.M., Silva L.H., Rosa P., Roland F. and Huszar V.L., 2012. Phytoplankton biomass is mainly controlled by hydrology and phosphorus concentrations in tropical hydroelectric reservoirs. Hydrobiologia, 693, 13-28.
Reynolds C.S., 1984. The Ecology of Freshwater Phytoplankton, Cambridge University Press, Cambridge, UK.

Reynolds C.S., 1997. Vegetation Process in the Pelagic: A Model for Ecosystem Theory, -Ecology Institute, Oldendorf, Luhe.

Reynolds C.S., 2006. The Ecology of Phytoplankton, Cambridge University Press, Cambridge, UK.

Reynolds C.S., Huszar V.L.M., Kruk C., Nasseli-Flores L. and Melo S., 2002. Towards a functional classification of the freshwater phytoplankton. J. Plankton Res., 24, 417-428.

Rigosi A. and Rueda F.J., 2012. Hydraulic control of short-term successional changes in the phytoplankton assemblage in stratified reservoirs. Ecol. Eng., 44, 216-226.

Rimmer A., Gal G., Opher T., Lechinsky Y. and Yacobi Y., 2011. Mechanisms of long-term variations in the thermal structure of a warm lake. Limnol. Oceanogr., 56, 974-988.

Rychtecký P. and Znachor P., 2011. Spatial heterogeneity and seasonal succession of phytoplankton along the longitudinal gradient in a eutrophic reservoir. Hydrobiologia, 663, 175-186.

Salmaso N., Naselli-Flores L. and Padisák J., 2015. Functional classifications and their application in phytoplankton ecology. Freshwat. Biol., 60, 603-619. doi: 10.1111/ fwb. 12520 .

Serra T., Granata T., Colomer J., Stips A., Møhlenberg F. and Casamitjana X., 2003. The role of advection and turbulent mixing in the vertical distribution of phytoplankton. Estuar. Coast Shelf Sci., 56, 53-62.

Sevindik T.O. and Çelik K., 2012. Phytoplankton composition of Ikizcetepeler Reservoir, Ballkesir-Turkey. OT Sistematik Botanik Dergisi, 19, 105-124.

Sevindik T.O., Çelik K. and Gönülol A., 2011. Twenty new records for Turkish freshwater algal flora from Çaygören and Ikizcetepeler Reservoirs (Ballkesir, Turkey). Turk. J. Fish. Aquat. Sci., 11, 399-406.

Silva C.A., Train S. and Rodrigues L., 2005. Phytoplankton assemblages in a Brazilian subtropical cascading reservoir system. Hydrobiologia, 537, 99-109.

State Water Works, 2005. Manyas Project, 25th Regional Branch, Balıkesir, Turkey.

Strickland J.D.H. and Parsons T.R., 1972. A practical handbook of seawater analysis (2nd edn), Bulletin of the Fisheries Research Board of Canada No. 167, Alger Press Ltd., Ottawa.

Sun J. and Liu D., 2003. Geometric models for calculating cell biovolume and surface area for phytoplankton. J. Plankton Res., 25, 1331-1346.

Technicon Industrial Methods, 1977a. Nitrate and nitrite in water and wastewater. No. 158-71, W/A.

Technicon Industrial Methods, 1977b. Phosphate and silicate analysis in water and seawater. No. 253-280 E. Application note, UK.

Ter Braak C.J.F. and Smilauer P., 2002. CANOCO Reference Manual and CanoDraw for Windows user's Guide: Software for Canonical Community Ordination (version 4.5), Microcomputer Power, Ithaca (NY, USA).

Tremblay J.E., Klein B., Legendre L., Rivkin R.B. and Therriault J.C., 1997. Estimation of f-ratios in oceans based on phytoplankton size structure. Limnol. Oceanogr., 42, 595-601. 
Turkish Ministry of Environment and Forestry, 2007. The Environmental Report for the City of Balıkesir. Technical Report No. 2007/10. Turkish Ministry of Environment and Forestry, Ankara, Turkey.

Utermöhl H., 1958. Zur Vervollkommnung der quantitativen Phytoplankton Methodik. Mitteilung Internationale Vereinigung fuer Theoretische und Amgewandte Limnologie, 9, 1-38.
Wetzel R.G. and Likens G.E., 2000. Limnological Analysis, Springer, New York.

Xiao L.J., Wang T., Hu R., Han B.P., Wang S., Qian X. and Padisák J., 2011. Succession of phytoplankton functional groups regulated by monsoonal hydrology in a large canyonshaped reservoir. Water Res., 45, 5099-5109.

Zarfl C., Lumsdon A.E., Berlekamp I., Tydecks L. and Tockner K., 2015. Aquat. Sci., 77, 161-170. 